\title{
Empirical evaluation of the efficiency of the Iberian power futures market
}

\author{
Álvaro Capitán Herráiz ; Carlos Rodríguez Monroy ${ }^{1}$ \\ ${ }^{1}$ Department of Business Administration, Madrid Technological University - UPM (SPAIN) \\ alvarocapitan@,hotmail.com; crmonroy@,etsii.upm.es
}

Received October 2008

Accepted December 2008

\begin{abstract}
Market efficiency is analysed for the Iberian Power Futures Market and other European Power Markets, as well as other fuel markets through evaluation of ex-post Forward Risk Premium. The equilibrium price from compulsory call auctions for distribution companies within the framework of the Iberian Power Futures Market is not optimal for remuneration purposes as it seems to be slightly upward biased, though such a premium is not significant (only around $2 \%$ above the average of Settlement Prices). In the period considered (August 2006 to September 2008), monthly futures contracts behave similarly to quarterly contracts. Average risk premia have been positive in power and natural gas markets but negative in oil and coal markets. Different hypotheses are tested regarding increasing volatility with maturity and regarding Forward Risk Premium correlations (negative with variance of spot prices during delivery period and positive with skewness of spot prices during delivery period). Enlarged data sets are recommended for stronger test results. Energy markets tend to show limited levels of market efficiency. Regarding the emerging Iberian Power Futures Market, price efficiency is improved with market development and with further integration of European Regional Power Markets.
\end{abstract}

Keywords: Iberian power futures market, market efficiency, forward risk premium 


\section{Introduction}

Since its beginning in July 2006, the Iberian Power Futures Market managed by OMIP ("Iberian Forward Market Operator"), within the framework of the Iberian Electricity Market (MIBEL), has experienced a continuous development, in terms of number of participants and liquidity. At this moment, 28 market players participate in OMIP. Almost half of them (12) belong to Iberian energy incumbents (vertically integrated energy groups with separated generation and distribution companies). Only 6 members are pure financial agents, still a reduced figure. Additionally, only one market maker has been active quoting monthly contracts in the periods September 2007 - March 2008 and May 2008 - October 2008. The main amount of traded energy in OMIP is still driven by compulsory call auctions according to national regulations aimed at fostering the MIBEL. The Spanish Distribution Companies and the Portuguese Last Resort Supplier with more than 100.000 clients are obliged to purchase in these auctions, in order to partly cover their portfolios of end-user regulated supplies. Such an obligation comprises $5 \%$ of their regulated supplies, for the second half of year 2006, as agreed by MIBEL Council of Regulators in the Évora Summit (November 2005), and published in the corresponding legislation (Spanish Order ITC/2129/2006 and Portuguese "Portaria" 643/2006), and 10\% for year 2007 onwards, as agreed in the Badajoz Summit (November 2006), and published in Spanish Order ITC/3990/2006 and Portuguese Dispatch 780/2007 (for first half of year 2007), Spanish Order ITC/1865/2007 and Portuguese Dispatch /2007 of 29 June 2007 (for second half of year 2007 and first half of year 2008), and Spanish Order ITC/1934/2008 and Portuguese Dispatch 19098/2008 (for second half of year 2008) (Fernández \& Xiberta, 2007).

As shown in Figure 1, since the last quarter of 2007 the amount of energy traded in the OMIP Continuous Market has grown slightly compared to previous trading levels, with a record in June 2008, though it is still less than the auctioned amounts. In the period spanning from the start of OMIP Continuous Market (July

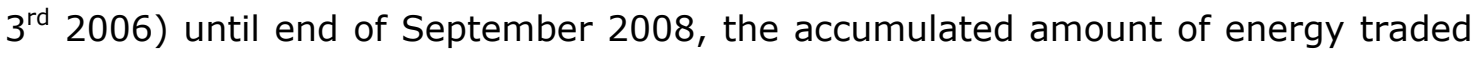
in OMIP call auctions is more than five times bigger than in the continuous market. Despite the record level in June 2008, no generalised trend of increasing volumes is appreciated in the continuous market. In the compulsory call auctions, the volumes tend to differ each 6 months due to introduction of the aforementioned regulation (Spanish "Order ITC" or Portuguese "Despacho"). Therefore, liquidity of this market is still reduced compared to other European Power Futures Markets. 


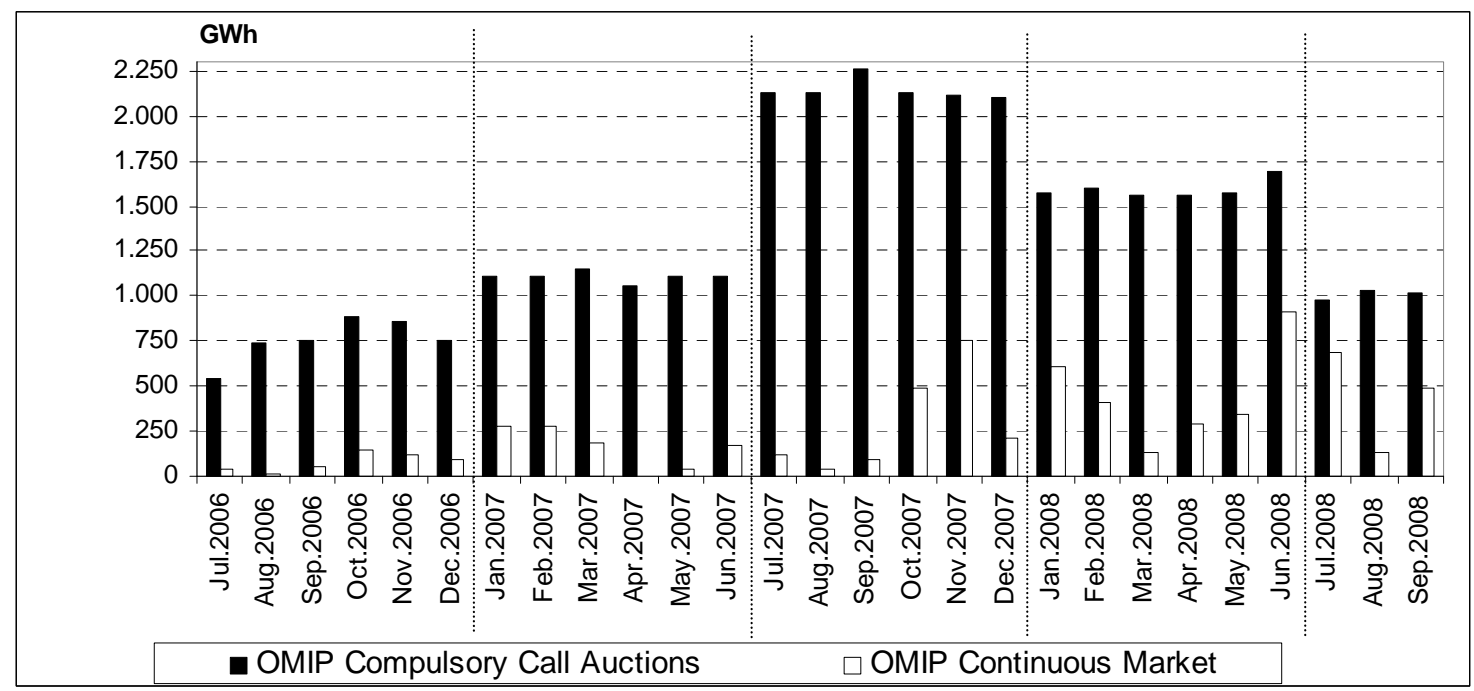

Figure 1. "Evolution of trading levels (GWh) in OMIP Call Auctions and OMIP Continuous Market". Source: OMIP

Empirical evaluation of the Efficiency of the Iberian Power Futures Market is done to assess the situation of this emerging market. This information is of special interest both for all MIBEL market players and for MIBEL Regulatory Committee in charge of MIBEL market supervision. This Committee is composed of the national energy and securities regulatory agencies, namely, Spanish CNE (Comisión Nacional de Energía) and CNMV (Comisión Nacional del Mercado de Valores), and Portuguese ERSE (Entidade Reguladora do Sector Energético) and CMVM (Comissão do Mercado de Valores Mobiliários), as established in the "Agreement between the Portuguese Republic and the Kingdom of Spain relative to the constitution of an Iberian Electrical Energy Market" - the so-called MIBEL Agreement - signed by the respective governments, on October $1^{\text {st }} 2004$.

In order to perform this evaluation, literature review regarding market efficiency is done. Diverse tests are performed to assess if the price formation in OMIP call auctions is satisfactory, and to compare OMIP settlement prices with other European Power Futures Markets as well as other Fuel Markets. In all these tests, the studied parameter is the ex-post Forward Risk Premium, defined as the difference between the average settlement price of a futures contract and the resulting average spot price during delivery (Furió \& Meneu, 2007). The methodology employed in each test and its derived results are provided in separate Sections, one per each test. Finally, the conclusions of this study summarise the findings of this research. 


\section{Literature review about market efficiency}

A short literature review of Market Efficiency is provided, focused on energy markets, and especially, in power markets compared to other commodities and to other financial markets. Market efficiency mainly refers in this context about how well the future price predicts the spot price.

Cointegration tests as well as tests for measuring if the forward price is an unbiased forecast for cash price for commodity and power markets show that Futures Markets are efficient in the long-term, but not in the short-term, even if risk neutrality is neglected and a risk premium is assumed. In practice, the hypothesis claiming that forward price is an unbiased forecast of future cash price ("Efficient Market Hypothesis") is usually rejected (Engel, 1996).

According to statistics and econometric research, many commodity futures markets existing since the middle of the $19^{\text {th }}$ Century are not efficient. Power Markets are considerably younger than Commodity Markets due to the deregulation trend in the 90's. Power Markets differ from other markets since electricity storage is very limited. There are many studies for the US and European Power Markets, analysing the behaviour and interactions of their different regional markets. Nord Pool is the oldest Power Exchange. It was founded as a Norwegian Power Exchange in 1993 ("Statnett Marked AS") and became a Nordic Power Exchange in 1996 as the Swedish System Operator (Svenska Kraftnät) became one of the main shareholders. In 1998 Finland enrolled to this market, followed by Western Denmark in 1999, and by Eastern Denmark in 2000. Power markets differ from other markets as the underlying good is fundamentally not storable. Nevertheless, in the Nordic market, a significant part of power production is from hydro reservoirs, playing such hydropower inventory an important role in the pricing of electricity (STEM, 2006).

Regarding energy markets, Serletis (1992) examines the effects of maturity on futures price volatility and trading volume for 129 energy futures contracts traded in New York Mercantile Exchange (NYMEX) in the beginning of the 90's. The results provide support for the maturity effect hypothesis theoretically demonstrated by Samuelson (1965). In the empirical research performed by Serletis, energy futures prices do become more volatile and trading volume increases as futures contracts approach maturity. As the majority of the studies testing Samuelson hypothesis 
are applied for US Futures markets, Allen and Cruickshank (2002) prefer to research with commodity futures on the Sydney Futures Exchange (SFE), the London International Financial Futures and Options Exchange (LIFFE), and the Singapore International Monetary Exchange (SIMEX). They also find evidence of Samuelson hypothesis in the majority of the contracts analysed. Samuelson assumed that competitive forces in the futures market cause spot and futures price to converge at expiry. Futures price volatility can be associated with the amount of information available in a market. Little information is known regarding distant contracts compared to contracts closer to expiration. Thus as maturity approaches, the amount of information reflecting the fundamentals of the spot asset increases, causing large changes in the futures prices and consequently intensifying price volatility. These results are important to many participants in futures markets as volatility has implications for hedgers and speculators who try to optimise their positions with respect to the level of price variability. In markets compliant with Samuelson hypothesis, speculators may find it beneficial to trade in contracts closer to expiry as greater volatility implies greater short-term profit opportunities. Hedgers would benefit from trading in longer dated contracts as lower volatility would require less hedges.

Regarding US Power markets, there are many studies comparing different regional markets. Research by Arciniegas, Barrett and Marathe (2003) shows that the Pennsylvania/New Jersey/Maryland (PJM) Power Market and the California Power Market are more efficient than the New York Power Market. They find that efficiency has risen with the maturity of the markets, as players have learnt to take advantage of arbitrage opportunities. They also find that a multi-settlement scheduling system leads to higher efficiency. A multi-settlement system implies that the prices and quantities established in market phases prior to dispatch are binding forward contracts. Their study is built with hourly prices of day-ahead and real-time markets. They consider that a market is efficient when all the relevant and ascertainable information is fully and immediately reflected in market prices. Therefore all players are well informed and adjust their market strategies to profit from arbitrage opportunities. Their literature review confirms that important differences in market structure and in the organisation of forward markets across US states may explain differences in market efficiency. California was the only market where competing scheduling coordinators ran the forward markets. In PJM and New York markets, the Independent System Operator (ISO) who centralized 
the day-ahead market competed with bilateral markets. An ISO can use its power as grid manager to favour its day-ahead market undermining its efficiency. In the summer of 2000 in California, one player (PG\&E) tried to exercise monopsony power, being this a possible cause of the large differences between the forward and spot prices in that period. PJM is the most liquid market in the East coast due to its bigger number of participants attracted because of lower transaction costs and by PJM reputation of delivering transparent and reliable information. New York power market lacked transparency in delivering information. They claim that more aggressive competition should lead to faster learning and more efficiency. In PJM, where utilities could fix prices through long term contracts, price volatility was less than in California, where utilities were not allowed to access to long term contracts and more than $90 \%$ of the power was purchased in the spot market. The lower volatility in energy prices may lead to fewer arbitrage opportunities and a more efficient and stable market. Good interconnection of regional markets brings efficiency and stability in the involved power markets. Additionally, disparity in the competition level of international power markets arises from differences in market design. Avsar and Goss (2001) study market efficiency for the PJM and the California Power Markets and cannot reject the Efficient Market Hypothesis for the period July 1998-March 1999, but cannot accept it for the whole data period. They find remarkable learning effects from market agents. Additionally, market efficiency is linked to market maturity. In this sense, market players in Power Markets seem to learn faster than in oil markets, for instance, increasing its efficiency with time (Walls, 1999). Bessembinder and Lemmon (2002) consider that electricity cannot be economically stored and therefore, arbitrage-based methods are not applicable for pricing power derivative contracts. They build an equilibrium model implying that the forward power price is a downward biased predictor of the future spot price if expected power demand is low and demand risk is moderate. The equilibrium forward premium increases when either expected demand or demand variance is high, due to positive skewness induced in the spot power price distribution. Optimal forward positions for power producing and retailing firms depend on forecast power demand and on skewness of power prices. Premium in forward power prices is positively related to expected demand, and is large during summer. Shawky, Marathe and Barrett (2003) attribute the high price volatility of US deregulated power markets to the nature of how electricity is produced and consumed, inelastic demand, seasonal effects and nonstorability of electricity. They investigate the empirical relation between daily spot and futures 
electricity prices traded on NYMEX and delivered at California-Oregon Border (COB) during years 1998-1999. They find that the behaviour of the electricity market is consistent with efficient markets. Due to unique features of electricity as a nonstorable commodity and the relatively few players on the generation and wholesale demand sides, they find that electricity futures differ significantly from other commodities as the former present larger estimates of forward risk premium and larger hedge ratios. The hedge ratio is defined as the ratio of the position taken in the futures contracts that will exactly offset the size of the exposure in the spot market. The larger forward risk premium may be required to bring equilibrium to a futures market where supply and demand conditions are much volatile and may also be caused by limited participation of financial players. Due to the unique characteristics of electricity, the price volatility in the spot market is many times higher than in the futures market. Positive shocks to spot prices have significantly more impact on both current and futures values of electricity than shocks to futures prices. Shocks to both spot and futures returns appear to be relatively short-lived (half-life of 4-5 days) before they converge to their long-run equilibrium.

Regarding European power markets, the largest number of studies exists for Nord Pool, the most developed power market in Europe since its foundation in 1993 (e.g. Byström, 2003). Byström concludes that traditional simple price hedging models are almost equally efficient as the most advanced ones. Therefore, hedging at Nord Pool (or whatever Power Futures Market) does not request more advanced models than from other financial markets though underlying product features differ noticeably from other financial or commodities products. Lucia and Schwartz (2000) analyse Nord Pool spot, futures and forward prices during years 1998-1999 and conclude that the seasonal systematic pattern of spot electricity prices throughout the year is of crucial importance in explaining the shapes of the futures and forward curve. They detect that a simple sinusoidal embedded in their one and two factor models captures the seasonal pattern of the futures and forward curve. Their models include a deterministic component reflecting remarkable regularities in the behaviour of electricity prices. They find that volatility of Nord Pool spot system price is consistently different between cold and warm seasons. They detect that transportation constraints for electricity make electricity contracts and prices highly local, i.e. strongly dependent on the local determinants of supply and demand (e.g. local generation plants, local climate, and local uses of electricity). 
Additionally, regulatory issues such as market rules and market structure may also impact on prices behaviour in competitive electricity markets and on their differences across countries.

The researches regarding European markets are usually focused on the Regional Integration of the Power Markets (e.g., Armstrong and Galli, 2005; Zachmann, 2005). Armstrong and Galli study European wholesale spot power prices and detect a price convergence between the price differences. Zachmann also finds a price convergence during the 2002-2004 period between Dutch and German wholesale power prices but not between East Danish and German prices. He concludes that it is necessary to overcome the bottlenecks in the physical interconnection capacity in order to achieve an integration of the European Power Market.

Conclusions from existing studies measuring the efficiency of Futures Markets vary considerably. Reviewed literature shows no uniformity regarding the results provided by the existing measuring methods. The selected method can slightly bias the results. Additionally, the most advanced models may question previous results from older and simpler models. More advanced models tend to confirm market efficiency but older ones may be prone to reject it. In general, it seems that commodity, energy, and even power markets are not especially efficient (STEM, 2006).

\section{Ex-post forward risk premium definition}

This research is focused on the analysis of the Forward Risk Premium in the Iberian Power Futures Market comparing different settlement price criteria and comparing the magnitudes of such Risk Premium with other European Power Markets and even other Fuel Markets of interest. There are some studies regarding market efficiency based on the evaluation of the Forward Risk Premium. Some of those studies are based on theoretical "ex-ante" analysis by modelling forecasted spot prices. Other studies use empirical data and evaluate "ex-post" differences between the Futures and Spot prices. This research represents an empirical evaluation using the "ex-post" Forward Risk Premium.

The "ex-ante" Forward Risk Premium (" $\Delta_{\text {ex-ante }}$ ") can be matematically expressed as follows: 


$$
\Delta_{\text {ex-ante }}=F_{t, T}-E_{t}\left(S_{T}\right)
$$

Equation 1. "Ex-ante Forward Risk Premium". Source: e.g. Bessembinder and Lemmon, 2002

Where $F_{t, T}$ refers to the Futures power price observed on day " $t$ " for delivery over period " $T$ ", and $E_{t}\left(S_{T}\right)$ refers to Expected Spot price on day " $t$ " for delivery over period " $T$ ".

The "ex-post" Forward Risk Premium (" $\Delta_{\text {ex-post }}$ ") can be matematically expressed as follows:

$$
\Delta_{\text {ex-post }}=\mathrm{F}_{\mathrm{t}, \mathrm{T}}-\operatorname{Average}\left(\mathrm{S}_{\mathrm{T}}\right)
$$

Equation 2. "Ex-post Forward Risk Premium". Source: e.g. Bessembinder and Lemmon, 2002

Where Average $\left(\mathrm{S}_{\mathrm{T}}\right)$ refers to average spot price for delivery over period $\mathrm{T}$.

In this research, the considered Futures contracts are baseload and with monthly and quarterly maturity. Three European Power Markets are considered, with all their prices in $€ / M W h$ : OMIP (Iberian Market; the underlying spot prices are taken from OMIE, "Iberian Energy Market Operator, Spanish Pool"), Powernext (French Market), and Nord Pool (Nordic Market). The considered fuel markets correspond to oil (InterContinental Exchange (ICE) Brent futures; only monthly futures are analysed, expressed in US\$/Bbl), natural gas (ICE monthly futures and Over The Counter (OTC) quarterly Platts' assessments, all related to the British National Balancing Point (NBP), and expressed in GB pence/therm), and coal (European Energy Exchange (EEX) Amsterdam-Rotterdam-Antwerp (ARA) Coal Futures, related to the underlying Argus McCloskey weekly spot index, expressed in US\$/t).

As different monetary units and energy units are used (original units for each market), Forward Risk Premium expressed in percentage over the futures price is preferred when comparing all these markets. Such an expression is matematically written as follows:

$$
\Delta_{\text {ex-post }} \%=\left[F_{t, T}-\text { Average }\left(\mathrm{S}_{\mathrm{T}}\right)\right] / \mathrm{F}_{\mathrm{t}, \mathrm{T}}
$$

Equation 3. "Ex-post Forward Risk Premium, in percentage over Futures price". Source: Furió and Meneu, 2007 
The selected period for the study embraces since the very beginning of OMIP market (first trading day was July $3^{\text {rd }}$ July 2006) until the end of September 2008. Therefore, the monthly contracts span from August 2006 to September 2008, and the quarterly ones from Q4-06 to Q3-08.

\section{Test 1: Efficiency assessment of OMIP Call Auction Equilibrium Prices}

\subsection{Methodology}

As mentioned in the Introduction, the Spanish Local Distribution Companies (and the Portuguese Last Resort Supplier) are obliged to purchase during the second half of year $20065 \%$ of their regulated power supplies (10\% from year 2007 onwards) in OMIP call auctions. If they do not comply with such obligations, each national regulation establishes different penalties. Due to that fact, those companies are satisfactorily purchasing their required amounts in all the OMIP call auctions. According to the legislation mentioned in the Introduction ("Orders ITC"), the cost of the energy purchased by the Spanish Distribution Companies in the OMIP call auctions is recognised through the resulting equilibrium price of each call auction.

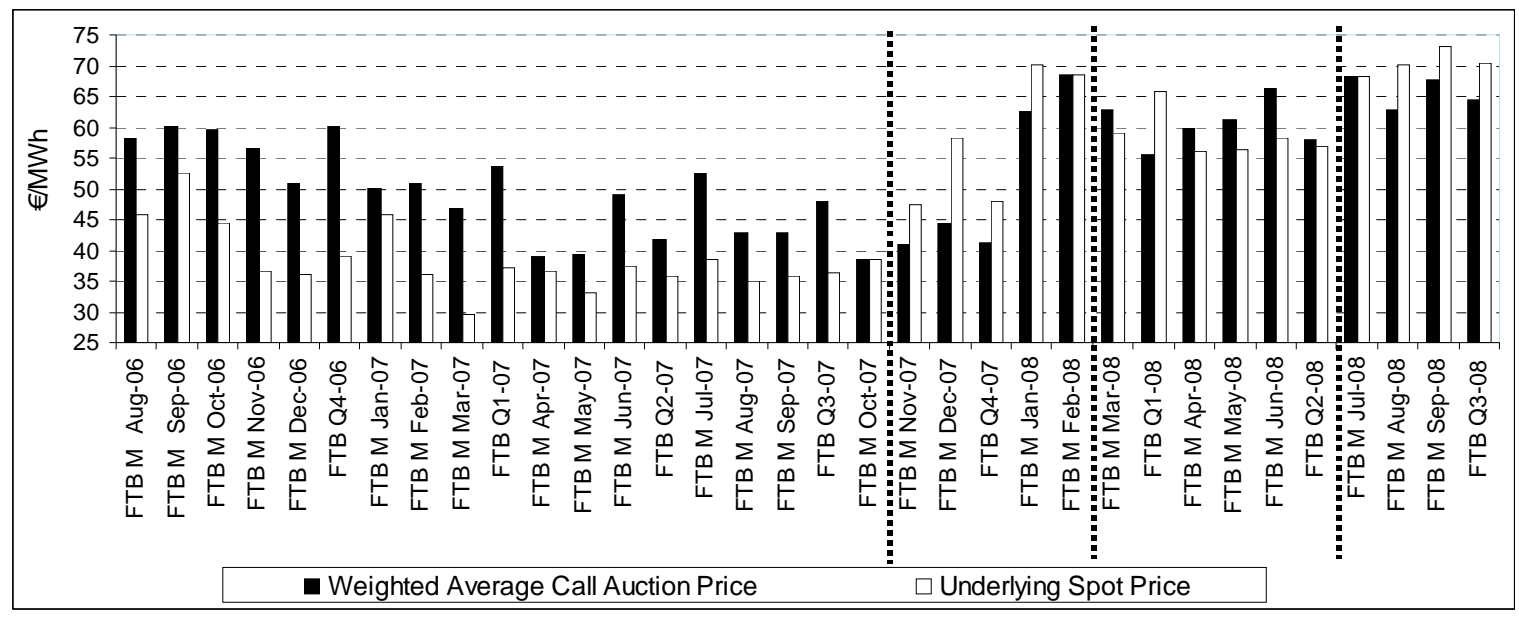

Figure 2. "Evolution of resulting Weighted Average Equilibrium Prices in OMIP Call Auctions versus Average Underlying Spot Prices". Source: OMIP, OMIE

Since the start of OMIP (in terms of quarterly periods, from Q4-06), all the auctioned settled contracts have experienced positive Forward Risk Premia until October 2007 (in terms of quarterly periods, until Q4-07), when a trend change is appreciated and negative Risk Premia become dominant during quarters Q4-07 and 
Q1-08. The Forward Risk Premium is again positive along Q2-08, but again negative along Q3-08, as shown in Figure 2 (dotted lines separate those price trends). This chart shows that OMIP Forward Risk Premium tends to diminish with time, and it is alternating positive and negative values more frequently, therefore price efficiency is improved with OMIP market development.

As the purchasing costs for the distribution companies are recognised, Test 1 assesses the costs of OMIP auctions distinguishing between monthly and quarterly contracts. Additionally, as calendar futures contract with delivery during year 2008 (FTB YR-08) has also been traded in such OMIP Call Auctions, estimation of the costs is also calculated for this contract considering the available spot data so far, i.e., from January 2008 to September 2008. Three different reference prices are employed:

- Resulting Auction Equilibrium Price $\left(" \mathrm{~F}_{\mathrm{eq}}{ }^{\prime \prime}\right)$ : this is the price recognised to the distribution companies, as stated above. It is calculated as the weighted average price of all the volumes acquired by the distribution companies in the call auctions celebrated for each futures contract.

- Average Futures Price for all the quotation period (" $\left.F_{\text {all }}\right)$ : this is the average price of all the Daily Settlement Prices published by OMIP along the whole quotation period of the futures contract. The algorithm employed by OMIP for determining the Daily Settlement Price, based on the traded prices and the bid-ask spread, is described in Section C.6 (Settlement Price Calculation) of OMIP OMIClear Operational Guide (version of June 2008). OMIP is the Market Operator and OMIClear is the Clearinghouse of the Iberian Power Futures Market. The algorithm can be summarised as follows:

o The Settlement Price for a futures contract is the last traded price if it is within the closing bid-ask spread

o If the last traded price during the trading session is not situated in the closing bid-ask spread, the settlement price is the bid or ask price closest to the last traded price.

o If there is no traded price during the trading session, the settlement price is the average of the bid-ask corresponding to the closing spread. 
o If there is no traded price during the trading session, and no closing bid-ask spread, the settlement price corresponds to the settlement price of the previous trading session.

o Nonetheless, when OMIP does not rely on the resulting price due to scarce negotiation of the contract, OMIP consults a Price Committee - composed voluntarily by Trading Members - and the daily price is obtained from representative quotations of the OTC market. Additionally, OMIP often employs the arbitrage criterion between a quarterly contract and their comprised monthly ones, to obtain the settlement prices by using weighted averages among these 4 contracts. It also applies arbitrage criterion between a calendar contract and their comprised quarterly ones. This is due to the fact that as other forward market mechanisms coexist with OMIP call auctions within MIBEL context (Virtual Power Plant auctions - "VPP auctions" -, known in Spanish as "Emisiones Primarias de Energía" or "EPE auctions", and Last Resort Supply auctions or "CESUR auctions" from the Spanish expression "Contratos de Energía para los Suministros de Último Recurso"), the most traded contracts in OMIP are the prompt months and quarterly ones (quarterly contracts with the same maturity as those from EPE and CESUR auctions), being the settlement prices of the least traded contracts in OMIP obtained through this arbitrage criterion.

- Average Spot price (" $\mathrm{S}$ "): this is the average price resulting from the Spanish Power Pool day ahead prices and corresponding to the whole delivery period of the considered futures contract. This Power Pool is managed by OMIE (known traditionally as "OMEL").

\subsection{Results}

Figure 3 shows the evolution of $\Delta_{\text {ex-post }} \%$ according to the three reference prices stated in the Methodology and the two quotation periods considered. 
OMIP Risk Premia (AvgeF M $_{\text {AvgeS }}$ deliv)/AvgeF $F_{M} \%$ for Monthly Contracts with different Reference Prices

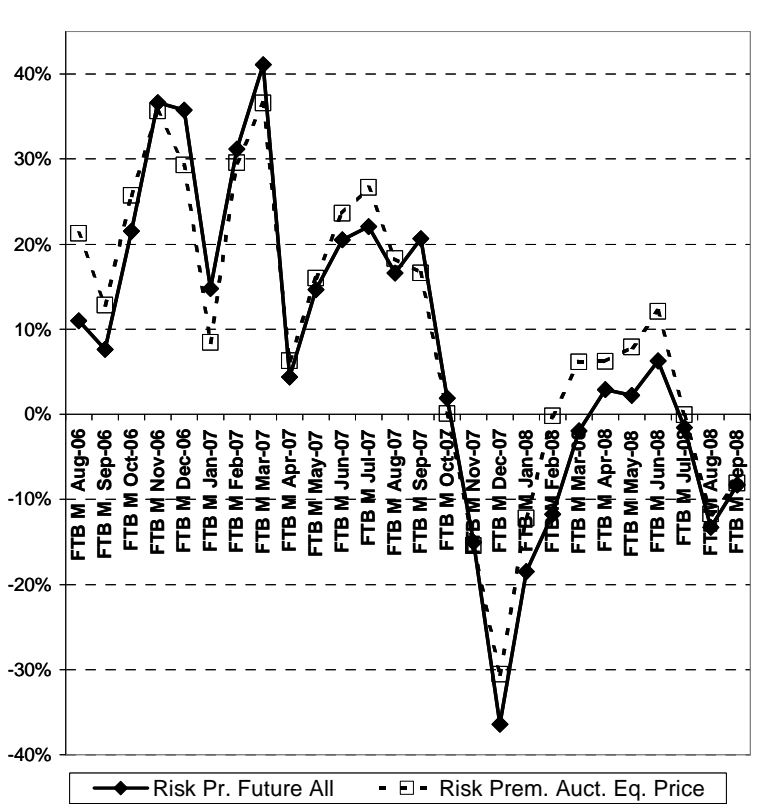

OMIP Risk Premia (AvgeF -AvgeS $_{\text {deliv }}$ )/AvgeF $\mathrm{A}_{\mathrm{Q}} \%$ for Quarterly Contracts with different Reference Prices

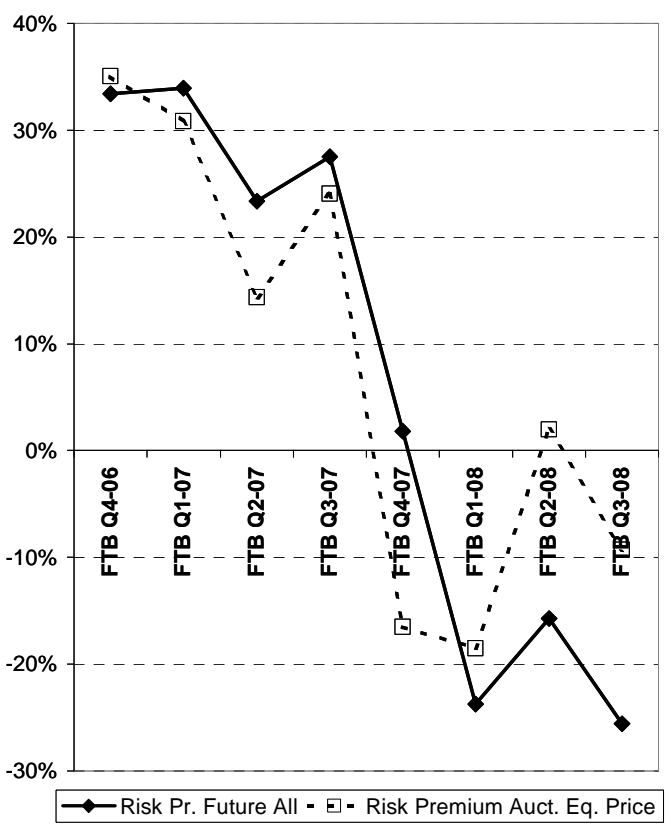

Figure 3. "OMIP Risk Premia in different quotation periods with different Reference Prices". Source: OMIP, OMIE

From Figure 3 it can be observed - especially for the monthly contracts - that $F_{\text {all }}$ provides smaller economic values both for the positive and negative premia periods than the official recognised price $\left(F_{e q}\right)$, as $F_{\text {all }}$ presents smaller positive forward risk premia and bigger negative ones (in absolute value) than $F_{\text {eq. }}$. Therefore, the total economic costs do differ depending on which futures price is considered as reference. Additionally, from Figure 3 it can be seen that Forward Risk Premium with $F_{\text {all }}$ is less than Forward Risk Premium with $F_{\text {eq }}$ along year 2008.

Another analysis is performed for the total economic costs by distinguishing per contract type (monthly versus quarterly), as shown in Table 1. From Table 1, it can be seen that the costs of monthly contracts are 2,7\% higher $(2,2 \%$ higher for the quarterly contracts) considering the official recognised price $\left(F_{e q}\right)$ instead of the average quotation price $\left(F_{\text {all }}\right)$. Such differences in the costs show that there may slightly be more competitive pressure in OMIP call auctions for the quarterly contracts than for the monthly ones. This can be provoked by the interaction with the other coexisting MIBEL market mechanisms (EPE and CESUR auctions above mentioned) where quarterly contracts are also traded. However, this claim is not so strong as $F_{\text {eq }}$ has resulted bigger than $F_{\text {all }}$ for the already expired quarterly 
contracts of year 2008 (from Q1-08 to Q3-08). This last difference is justified by the fact that these quarterly contracts began to quote in OMIP since the beginning of 2007 at very lower prices than in their last quotation months, due to the large impact of the historically maximum values experienced by the oil prices in those last quotation months (first half of 2008; the record oil price (spot) has been produced on July $\left.3^{\text {rd }}: 144,22 \$ / B b l\right)$. In order to draw stronger and more accurate conclusions, further research is encouraged by considering weighted average futures prices of OMIP Settlement Prices with the OMIP trading sessions where trades occurred. Additionally, it is interesting to see that for the whole considered period and taking into account the yearly contract, the total cost obtained through $F_{\text {all }}$ is similar to the cost in case that energy were purchased at the spot price. When considering $F_{e q}$, the total cost is still bigger than the cost derived from considering the spot price, due to the slight upward bias of $F_{\text {eq }}$ aforementioned.

\begin{tabular}{|c|c|c|c|c|}
\hline \multicolumn{6}{|c|}{ Costs Assessment of energy purchased in OMIP Auctions by Spanish Distribution Companies } \\
\hline Contract Type & MWh & $\boldsymbol{C ~ F ~ F l l ~}_{\text {al }}$ & $\boldsymbol{C ~ F}_{\text {eq }}$ & C Spot \\
\hline Monthly & 13.896 .691 & 776.330 .384 & 797.165 .235 & 741.443 .752 \\
\hline Quarterly & 9.467 .856 & 489.434 .596 & 499.984 .271 & 496.722 .862 \\
\hline Yearly & 2.051 .400 & 105.365 .705 & 105.788 .989 & 132.151 .757 \\
\hline Total & 25.415 .947 & 1.371 .130 .686 & 1.402 .938 .495 & 1.370 .318 .371 \\
\hline
\end{tabular}

Table 1. "Costs assessment of Energy purchased in OMIP Call Auctions by Spanish

Distribution Companies. Distinction per contract type". Source: OMIP, OMIE

From the results obtained, the following conclusions can be drawn:

- In the short term, until enough liquidity is reached in OMIP continuous market, it seems reasonable to continue arranging compulsory call auctions for the Spanish Distribution Companies. Nonetheless, the equilibrium price $\left(F_{\text {eq }}\right)$, used for the settlement of the purchased contracts, is resulting slightly higher compared to the average of settlement prices along the trading period of the contract $\left(F_{\text {all }}\right)$. According to OMIP trading limits for mitigating the members' credit risk - as theoretically defined in Section B2.12 Daily Price Variation Limits of OMIP Operational Guide and practically specified in OMIP Notice 04/2006 regarding Maximum Price Variation Limits - accepted bids and offers must be contained within an interval centered on the Trading Session Reference Price, i.e. the resulting Settlement Price of the previous session. In the case of yearly and quarterly contracts, the 
interval spans from the reference price $\pm 6 \%$ ( $\pm 9 \%$ for monthly contracts; $\pm 15 \%$ for weekly contracts). Spanish Distribution Companies and Portuguese Last Resort Supplier submit their compulsory bids in OMIP call auctions at the price given by the upper limit of the interval, in order to ensure that their bids are matched, and provoking that competition only arises from the sales side. If they submitted their bids at a maximum price which is somehow less, the resulting equilibrium price might diminish, as desired in terms of economic costs to the regulated supplies. Therefore, it might make sense that as soon as the settlement price of the previous session is determined, OMIP and MIBEL Regulators Committee may agree upon a cap price for the compulsory call auction of the following day. Such a cap price would be carefully calculated per auction, in order to get the desired effect on the auction equilibrium price without preventing competition on the sales curve. The cap price would only apply for the compulsory call auction, not for the continuous market, in order to limit such a regulatory intervention. For the sake of transparency, the auction cap price should be published in OMIP bulletin together with the results of the trading session previous to the compulsory call auction. This daily bulletin shows currently, per negotiated futures contract, all the traded volumes in OMIP continuous market, compulsory call auctions, and OTC settled by OMIClear. Furthermore, last traded price, open price, daily high and low prices, closing bid-ask spread, aggregated traded volumes distinguishing between financially and physically settled contracts (excluding OTC settled by OMIClear), and open interest are also shown.

- It may be reasonable to continue offering compulsory quantities via OMIP call auctions to distribution companies or last resort suppliers until desired liquidity levels are reached in the continuos market. At that stage, the Settlement Price published by OMIP should accurately reflect market prices and could be better utilised for the calculation of last resort supply costs. Distribution companies or last resort suppliers would then be able to cover their forward energy needs through OMIP continuous market. Therefore, further compulsory OMIP call auctions would no longer be necessary. Additionally, the competitive nature of the continuous market would theoretically provide smaller prices than compulsory auctions, making the supply costs more affordable to last resort suppliers. 


\section{Test 2: Analysis of Basic Statistics of Futures \& Spot Prices}

\subsection{Methodology}

Basic statistics (Average, Median, Maximum, Minimum, Standard Deviation, Asymmetry Coefficient, and Kurtosis) for the monthly and quarterly futures contracts and their underlying average spot prices are provided in order to compare all the energy markets considered. The data set is comprised of the arithmetical mean values for the settlement prices of each Futures contract during its quotation period. For the corresponding spot price, arithmetical mean for the underlying delivery period is calculated.

\subsection{Results}

Table 2 and 3 show basic statistics for the monthly and quarterly futures prices respectively:

\begin{tabular}{|c|c|c|c|c|c|c|c|c|c|c|c|c|}
\hline & \multicolumn{12}{|c|}{$\begin{array}{c}\text { Basic Statistics of Average Reference Prices of Monthly Contracts \& Underlying } \\
\text { Spot Prices. Period: Aug.06-Sep.08 }\end{array}$} \\
\hline & \multicolumn{2}{|c|}{$\begin{array}{c}\text { OMIP } \\
\text { (C/MWh) }\end{array}$} & \multicolumn{2}{|c|}{\begin{tabular}{|c|} 
Powernext \\
(C/MWh)
\end{tabular}} & \multicolumn{2}{|c|}{\begin{tabular}{|l|}
$\begin{array}{l}\text { Nord Pool } \\
\text { (C/MWh) }\end{array}$ \\
\end{tabular}} & \multicolumn{2}{|c|}{\begin{tabular}{|l} 
NBP (GB \\
p/therm)
\end{tabular}} & \multicolumn{2}{|c|}{$\begin{array}{c}\text { Brent } \\
\text { (US \$/Bbl) }\end{array}$} & \multicolumn{2}{|c|}{$\begin{array}{l}\text { EEX ARA } \\
\text { (US \$/t) }\end{array}$} \\
\hline & & Spot & & Spot & Future & Spot & & Spot & & Spot & & \\
\hline Ave & & 48,72 & & 49,94 & 43,95 & 37,88 & 48,15 & 39,85 & & & &, 04 \\
\hline Median & & 45,81 & 57,37 & 44,26 & 45,57 & 37,12 & 45,53 & 35,96 & 63,45 & 76,94 & 4,55 & 89,69 \\
\hline Max &, 44 & 73,03 & 82,89 & 88,43 & 63,17 & 67,47 & 80,08 & 69,87 & 81,99 & 133,18 & 169,31 & 209,73 \\
\hline Min & 38,35 & 29,68 & 27,87 & 27,02 & 23,77 & 16,53 & 26,48 & 16,24 & 51,02 & 53,91 & 62,63 & 65,70 \\
\hline Std.Dev. & 73 & 13,64 & 16,24 & 19,61 & 12,09 & 14,94 & 15,12 & 16,27 & 7,39 & 23,75 & 32,46 & 45,52 \\
\hline Asymmetry & $-0,22$ & 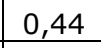 & $-0,06$ & 0,45 & $-0,12$ & 0,51 & 0,64 & 0,20 & 0,74 & & 1,00 & 0,75 \\
\hline Kurtosis & $-0,97$ & $-1,20$ & $-0,96$ & $-1,04$ & $-1,07$ & $-0,65$ & 0 & $-1,39$ & 0,11 & $-0,51$ & $-0,07$ & $-0,70$ \\
\hline
\end{tabular}

Table 2. "Basic Statistics of $F_{\text {all }} \&$ Underlying Spot Prices of Monthly Future Contracts during period Aug.06-Sep.08". Sources: OMIP, OMIE, Powernext, Nord Pool, Platts, ICE, EEX, Argus Mc Kloskey.

From the information reflected in the tables, the following conclusions can be drawn:

- Within each market and comparing Futures with Spot values, the same behaviour is detected for monthly and quarterly contracts, except for Asymmetry and Kurtosis. Nevertheless, as the data set is quite limited (especially for quarterly contracts), such differences are not relevant. 


\begin{tabular}{|c|c|c|c|c|c|c|c|c|c|c|}
\hline & \multicolumn{10}{|c|}{$\begin{array}{c}\text { Basic Statistics of Average Reference Prices of Quarterly Contracts \& Underlying } \\
\text { Spot Prices. Period: Q4 06-Q3-08 }\end{array}$} \\
\hline & \multicolumn{2}{|c|}{\begin{tabular}{|c|c|} 
OMIP \\
$(\boldsymbol{C} /$ MWh $)$ \\
\end{tabular}} & \multicolumn{2}{|c|}{$\begin{array}{l}\text { Powernext } \\
(€ / M W h)\end{array}$} & \multicolumn{2}{|c|}{$\begin{array}{l}\text { Nord Pool } \\
(\mathrm{C} / \mathrm{MWh})\end{array}$} & \multicolumn{2}{|c|}{$\begin{array}{c}\text { NBP } \\
\text { (GB p/therm) }\end{array}$} & \multicolumn{2}{|c|}{$\begin{array}{l}\text { EEX ARA } \\
\text { (US \$/t) }\end{array}$} \\
\hline & Future & Spot & Future & Spot & Future & Spot & Future & Spot & Future & Spot \\
\hline Average & 52,39 & 48,69 & 54,96 & 50,92 & 40,38 & 35,56 & 49,18 & 40,62 & 76,19 & 113,64 \\
\hline Median & 51,77 & 43,47 & 53,96 & 52,61 & 40,01 & 36,29 & 44,50 & 38,75 & 71,30 & 104,45 \\
\hline Max & 58,57 & 70,41 & 70,06 & 72,71 & 48,72 & 55,38 & 76,11 & 61,48 & 98,44 & 192,82 \\
\hline Min & 46,57 & 35,70 & 41,08 & 29,35 & 33,34 & 19,74 & 30,36 & 20,20 & 66,14 & 67,39 \\
\hline Std.Dev. & 4,30 & 14,04 & 10,73 & 19,63 & 5,08 & 12,18 & 15,62 & 16,88 & 11,45 & 46,88 \\
\hline Asymmetry & 0,15 & 0,65 & 0,16 & $-0,04$ & 0,42 & 0,22 & 0,94 & 0,09 & 1,24 & 0,62 \\
\hline Kurtosis & $-1,57$ & $-1,44$ & $-1,54$ & $-2,42$ & $-0,41$ & $-0,81$ & $-0,13$ & $-2,02$ & 0,70 & $-0,99$ \\
\hline
\end{tabular}

Table 3. "Basic Statistics of $F_{\text {all }} \&$ Underlying Spot Prices of Quarterly Future Contracts during period Q4.06-Q3.08". Sources: OMIP, OMIE, Powernext, Nord Pool, Platts, ICE, EEX, Argus

Mc Kloskey.

- The Average Risk Premia are positive in Power and Gas Markets, but negative in Oil and Coal Markets. To be more precise, in Power and Gas Markets the average Risk Premia of positive values tend to be bigger in absolute value than average Risk Premia of negative values. In Oil and Coal Markets, the average Risk Premia of negative values tend to be bigger in absolute value than average Risk Premia of positive values.

- According to standard deviation values, spot markets show bigger volatility than their related future markets. Due to that bigger volatility, more extreme values are presented in spot markets, with the exceptions of maximum values in gas forward market and minimum values in oil and coal futures markets. The biggest spreads (Futures versus Spot) regarding maximum values are produced for the oil and coal markets.

- In general, Asymmetry tends to be positive and Kurtosis tends to be negative.

- Although not reflected in the tables, similar results are obtained from OMIP $F_{\text {eq }}$ as those shown for OMIP $F_{\text {all }}$. 


\section{Test 3: Comparison of Futures Behaviour towards Maturity}

\subsection{Methodology}

For all the markets considered, distinguishing between monthly and quarterly futures contracts, and per approach to maturity (all quotation period (" $F_{\text {all }}$ "), third last month of quotation (" $\mathrm{F}_{\mathrm{M}-3}$ "), second last month of quotation (" $\mathrm{F}_{\mathrm{M}-2}$ "), and last month of quotation $\left.\left(" \mathrm{~F}_{\mathrm{M}-1}\right)\right)$, different magnitudes are compared:

- Assessment of similar behaviour between Monthly and Quarterly Contracts

- Quantitative comparison of $\Delta_{\text {ex-post }} \%$ between Monthly and Quarterly Contracts, and between Periods with positive or negative values

- Correlation between Futures Series $\left(F_{\text {all }}\right.$ versus $F_{M-3}, F_{M-2}$, or $\left.F_{M-1}\right)$

- Samuelson's hypothesis (1965): "Volatility increases as Futures contracts approach maturity"

- Increasing convergence to spot price (less $\Delta_{\text {ex-post }} \%$ in absolute value) with maturity
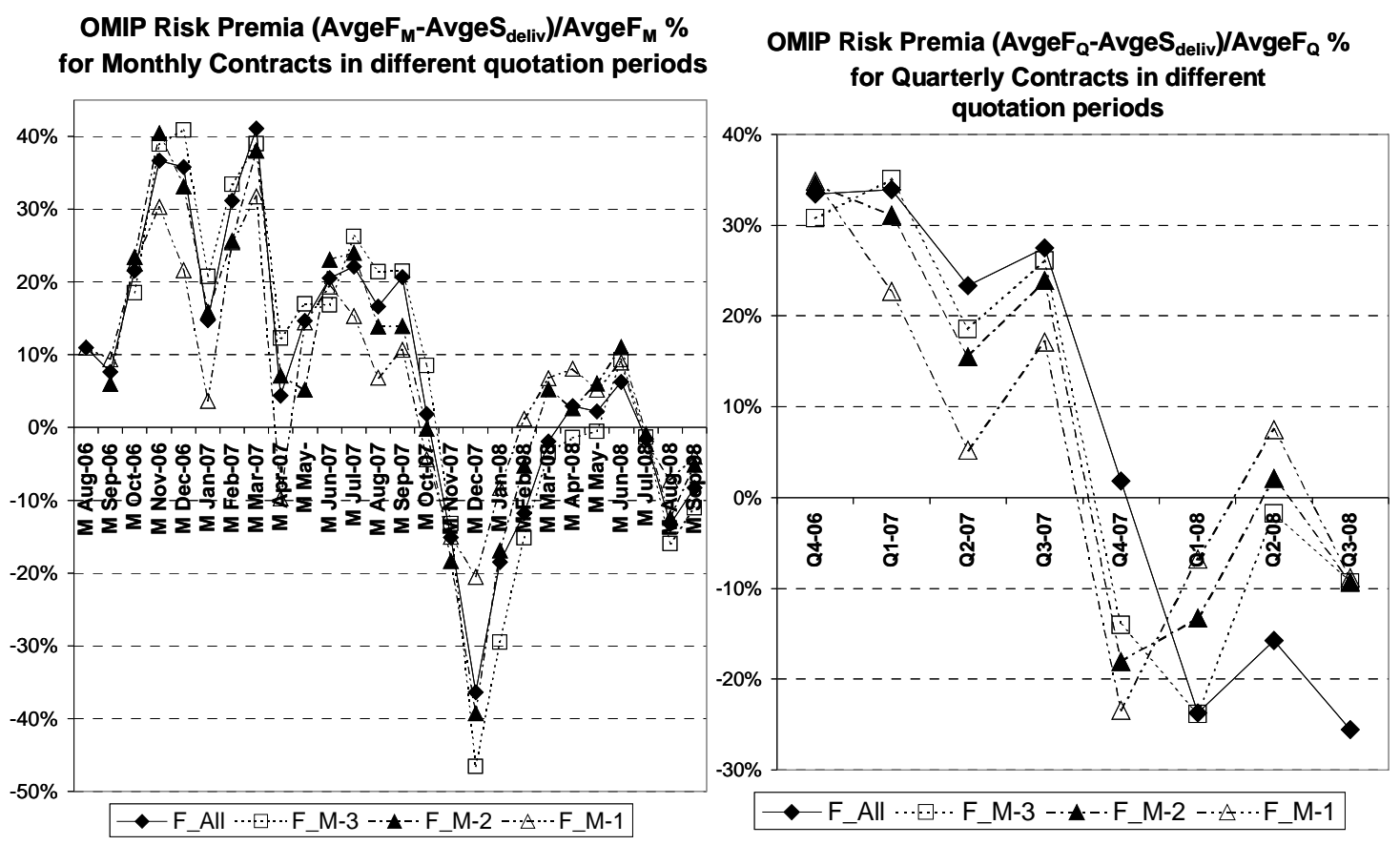

Figure 4. "OMIP Forward Risk Premia distinguishing Reference Prices per approach to maturity". Sources: OMIP, OMIE. 


\subsection{Results}

Figure 4 shows the evolution of the Forward Risk Premia (in percentage) for both monthly and quarterly OMIP futures contracts, considering the 4 series of futures prices: $F_{\text {all, }} F_{M-3}, F_{M-2}$, and $F_{M-1}$. Figures 5-9 show respectively the equivalent information for the rest of considered energy markets in this research, namely, Powernext, Nord Pool, NBP Gas, Brent, and EEX ARA Coal.

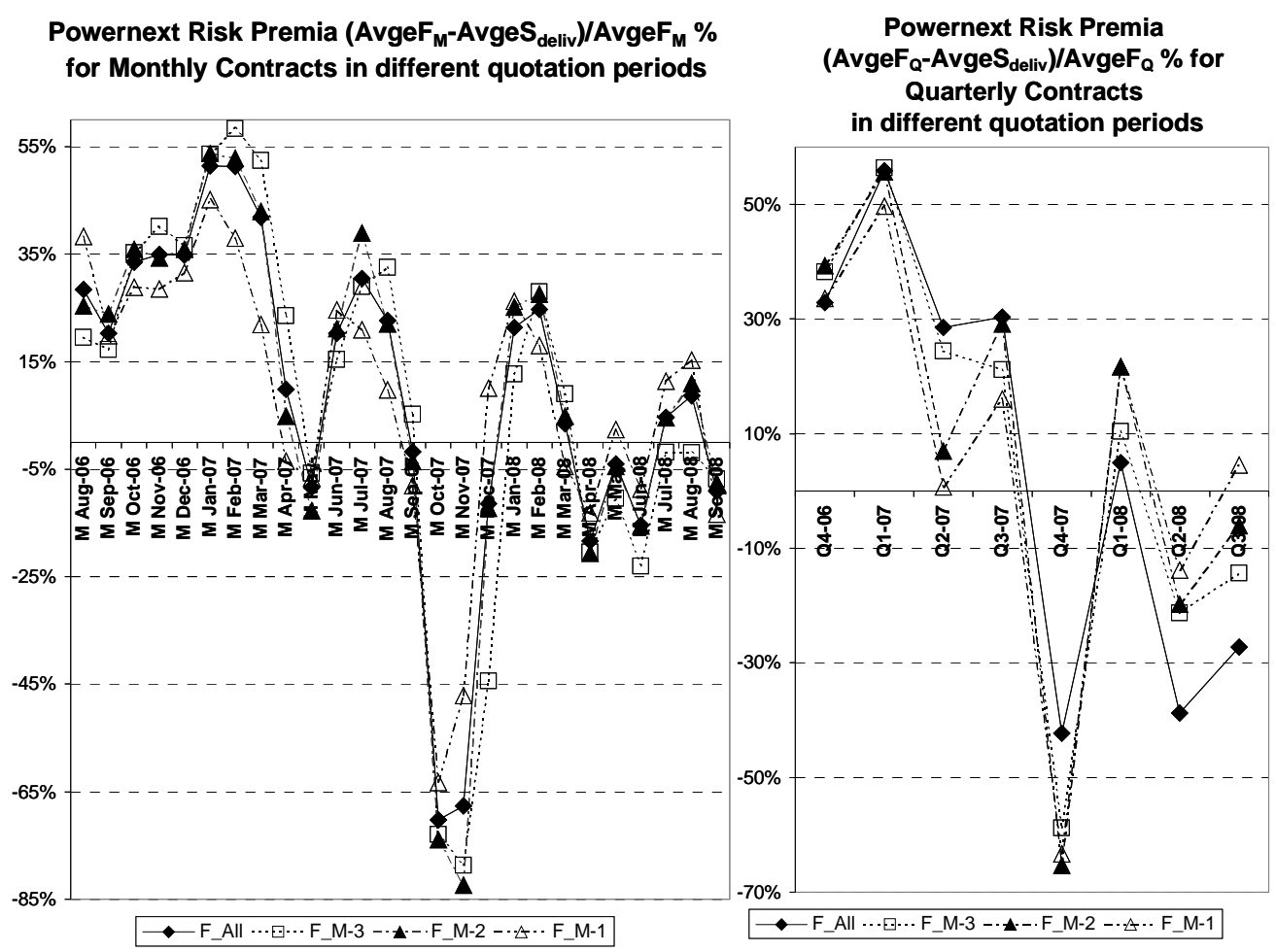

Figure 5. "Powernext Forward Risk Premia distinguishing Reference Prices per approach to maturity". Source: Powernext.

By analysing all these charts, various trends are detected. The following conclusions can be drawn from Figures 4-9:

- Monthly and Quarterly contracts have similar Forward Risk Premium variation trends coinciding with alternant periods of positive $\Delta_{\text {ex-post }} \%$ or negative $\Delta_{\text {ex-post }} \%$. In the case of power markets, a general trend change ("positive to negative") is produced in autumn 2007. 
Nord Pool Risk Premia $\left(\right.$ AvgeF $_{\mathrm{M}}-$ AvgeS $\left._{\text {deliv }}\right)$ /AvgeF $_{\mathrm{M}} \%$ for Monthly Contracts in different quotation periods

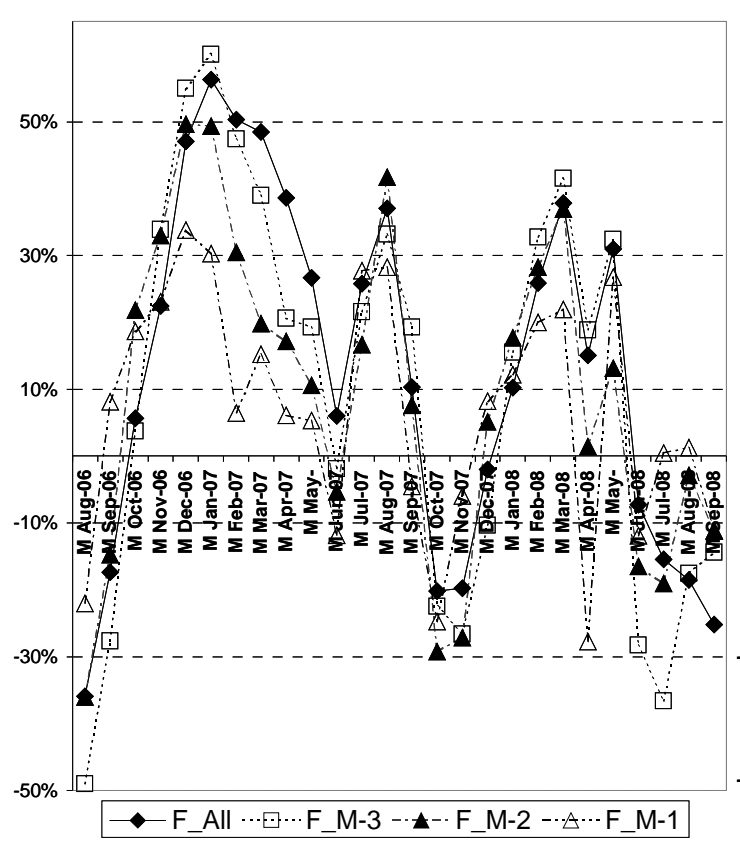

Nord Pool Risk Premia

$\left(\right.$ AvgeF $_{\mathrm{Q}^{-}}$AvgeS $\left._{\text {deliv }}\right) /$ AvgeF $_{\mathrm{Q}} \%$ for

Quarterly Contracts in

different quotation periods

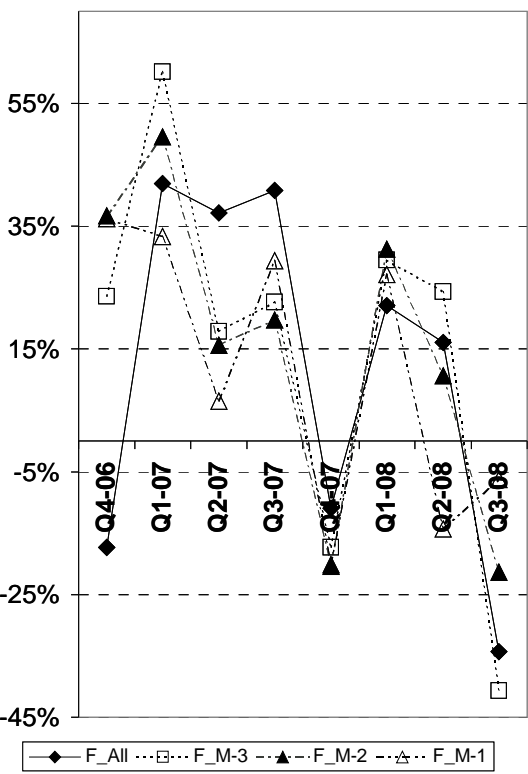

Figure 6. "Nord Pool Forward Risk Premia distinguishing Reference Prices per approach to maturity". Source: Nord Pool.
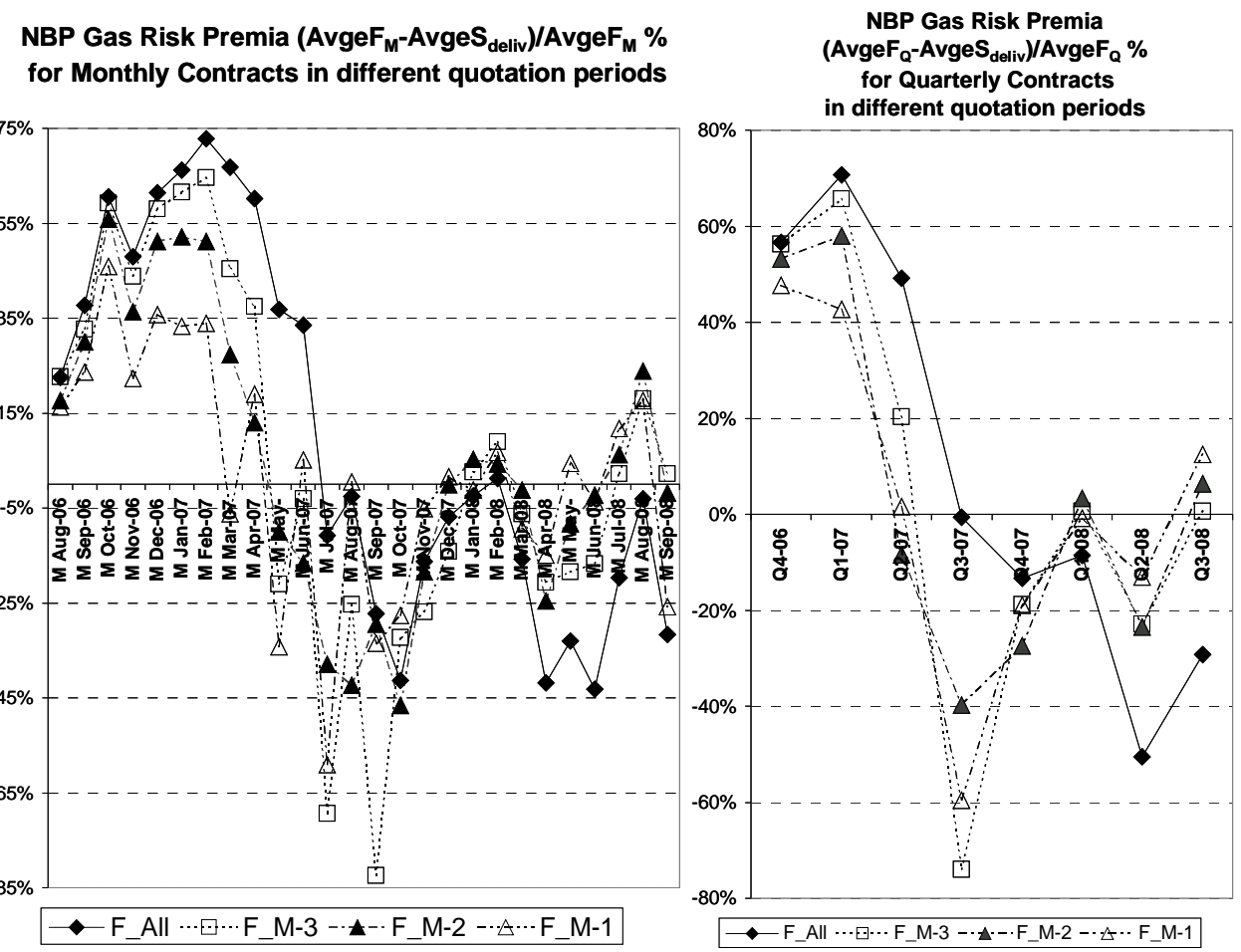

Figure 7. "NBP Gas Forward Risk Premia distinguishing Reference Prices per approach to maturity". Sources: ICE, Platts. 


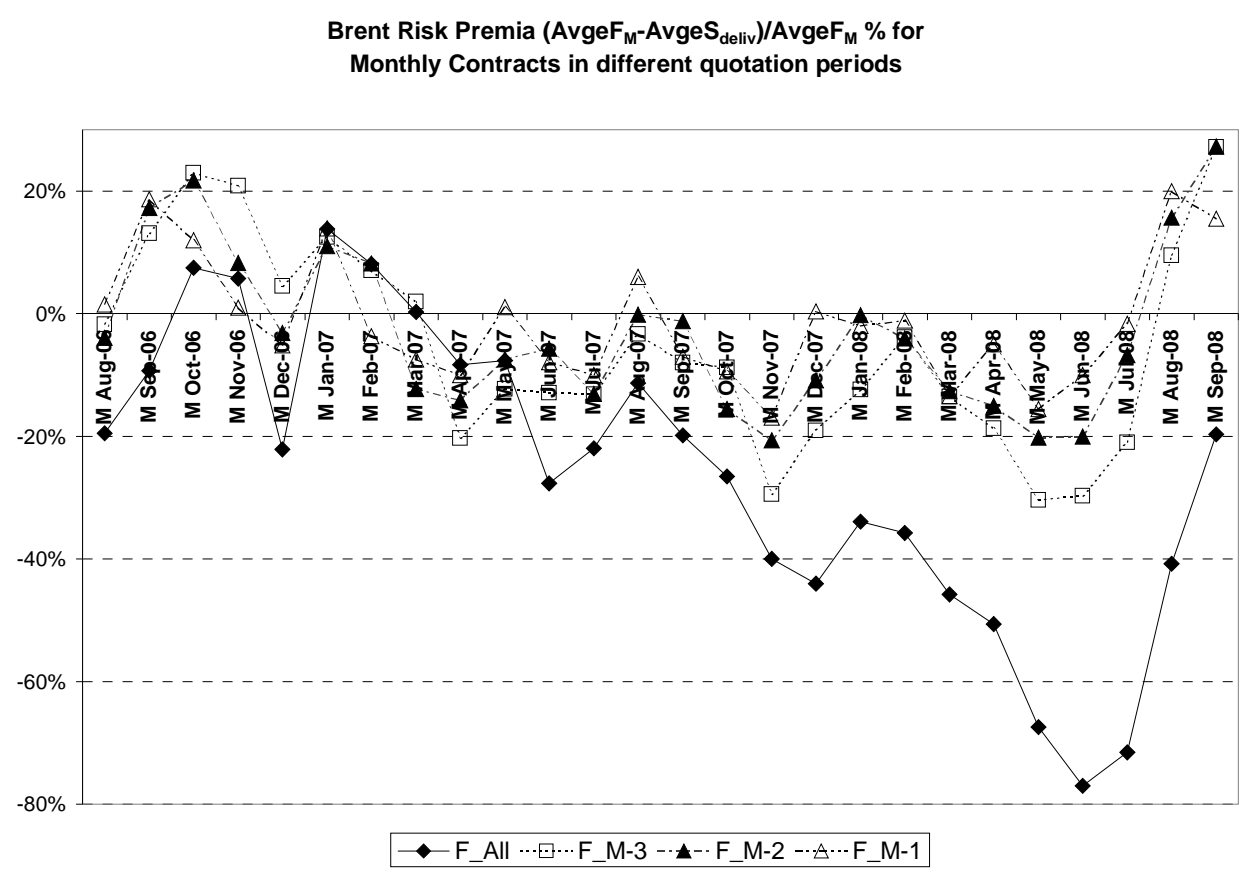

Figure 8. "Brent Forward Risk Premia distinguishing Reference Prices per approach to maturity". Sources: ICE, Platts.
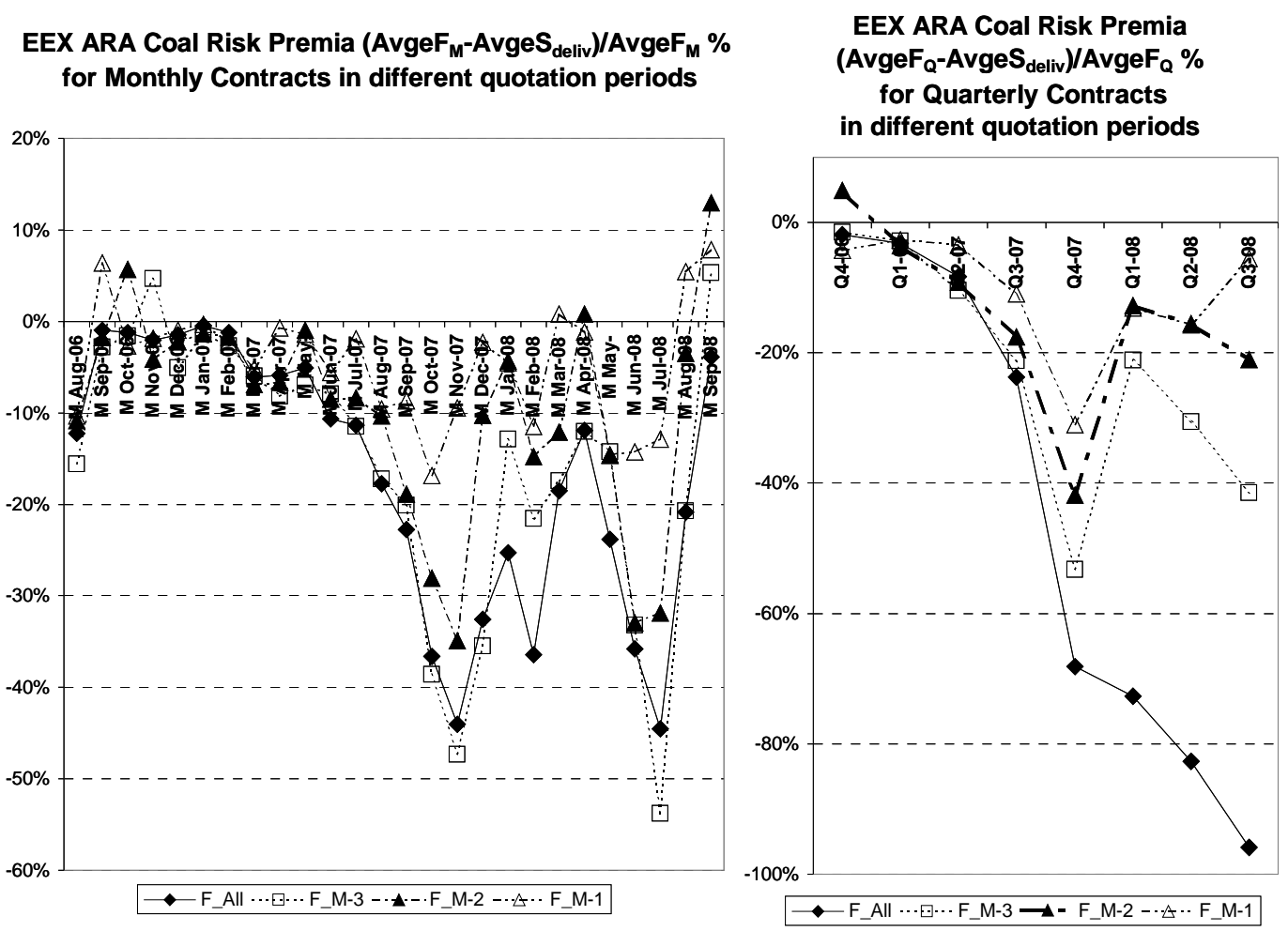

Figure 9. "EEX ARA Coal Forward Risk Premia distinguishing Reference Prices per approach to maturity". Sources: EEX, Argus Mc Kloskey. 
- Quantitative variations of $\Delta_{\text {ex-post }} \%$ are similar for monthly and quarterly contracts. Whereas monthly average values tend to be slightly smaller than quarterly ones, extreme monthly values tend to be somewhat bigger than quarterly ones, explained by slightly bigger volatility of the monthly values (measured in terms of standard deviation). Regarding extreme variations, the smallest ones occur for OMIP (around $\pm 40 \%$ ), and the biggest for NBP (around $\pm 70 \%$ ).

- Whereas $\Delta_{\text {ex-post }} \%$ positive is dominant in power and gas markets, $\Delta_{\text {ex-post }} \%$ negative is dominant in oil and coal markets, supposing different hedging strategies within each market. In absolute value, average positive $\Delta_{\text {ex-post }} \%$ tends to be slightly bigger than average negative $\Delta_{\text {ex-post }} \%$. Regarding extreme variations, in absolute value, negative $\Delta_{\text {ex-post }} \%$ tends to be slightly bigger than positive $\Delta_{\text {ex-post }} \%$

- Correlation between Futures Series ( $F_{\text {all }}$ with each of the 3 series $F_{M-3}, F_{M-2}$, or $\mathrm{F}_{\mathrm{M}-1}$ ) - analysing separately monthly and quarterly futures contracts - is only significant in EEX ARA Coal (correlation coefficient around 0,99). In the case of Power Markets, for the monthly contracts the correlation coefficients are around 0,90 and for the quarterly contracts, the correlation coefficients are around 0,70 . Smaller coefficients for quarterly contracts can be caused by the limited data set ( 8 values) compared to wider monthly data set (26 values). Comparing Power Markets, Powernext presents the biggest correlation coefficients and Nord Pool the smallest ones. For NBP Gas, correlation coefficients are around 0,60 for monthly and quarterly contracts. For Brent, correlation coefficients are around 0,90 (monthly contracts). For all the markets, the least correlation is produced between $F_{\text {all }}$ and $F_{M-1}$ (i.e. correlation tends to diminish as futures contracts approach maturity).

- Samuelson's maturity effect (increasing volatility when maturity approaches) is noticeable in all the markets considered except for the British gas market.

- Increasing convergence to spot price with maturity is fulfilled by all time series (trend towards smallest $\Delta_{\text {ex-post }} \%$ in absolute value, when comparing, in this sequence, $\mathrm{F}_{\mathrm{M}-3}, \mathrm{~F}_{\mathrm{M}-2}$, and $\mathrm{F}_{\mathrm{M}-1}$ ). Monthly and quarterly contracts are analysed separately, where comparison of $\Delta_{\text {ex-post }} \%$ in absolute value is 
separately done for positive $\Delta_{\text {ex-post }} \%$ and negative $\Delta_{\text {ex-post }} \%$. The convergence with maturity is caused due to lack of accuracy in oldest quoted futures prices, as less information was then available in the market.

\section{Test 4: Bessembinder's \& Lemmon's Hypothesis Compliance}

\subsection{Methodology}

For each futures contract type (monthly and quarterly, distinguishing between $\mathrm{F}_{\text {all, }}$ $\left.F_{M-3}, F_{M-2}, F_{M-1}\right)$ of the three considered European Power Markets, testable hypothesis from Bessembinder \& Lemmon (2002) is checked by using $\Delta_{\text {ex-post }}$ as the power prices in the three markets are commonly expressed in $€ / M W h$ :

$$
\Delta_{\text {ex-post }}=F_{t, T}-\operatorname{Average}\left(\mathrm{S}_{\mathrm{T}}\right)
$$

Equation 4. "Ex-post Forward Risk Premium". Source: e.g. Bessembinder \& Lemmon, 2002.

The testable hypothesis is as follows: "The Forward Risk Premium decreases in the variance of spot prices and increases in the skewness of wholesale prices". In order to test the hypothesis, linear regression is applied according to:

$$
\Delta_{\text {ex-post }}=a+\beta * \operatorname{VAR}\left(S_{T}\right)+\gamma^{*} \operatorname{ASIM}\left(S_{T}\right)+\varepsilon_{T}
$$

Equation 5. "Bessembinder's \& Lemmon's ex-post testable hypothesis". Source: Furió \& Meneu, 2007.

Where $a$ is a constant, $\beta$ and $Y$ are coefficients, $\operatorname{VAR}\left(S_{T}\right)$ reflects the variance of spot prices, $\operatorname{ASIM}\left(\mathrm{S}_{\mathrm{T}}\right)$ represents the non-standardised Asymmetry Coefficient ("skewness") of spot prices (it is the Asymmetry Coefficient multiplied by cubed Standard Deviation of Spot Prices), and $\varepsilon_{\mathrm{T}}$ is an error term.

Good compliance should render negative $\beta$, positive $\gamma$, with significant values for their t-statistics, as well as a high value of $\mathrm{R}^{2}$ statistic. For the t-Student tests, a level of confidence of $95 \%$ with 2 tails is considered.

\subsection{Results}

Table 4 summarises the results of applying multifactor linear regression: 


\begin{tabular}{|c|c|c|c|c|c|c|c|c|}
\hline \multicolumn{9}{|c|}{$\begin{array}{l}\text { Bessembinder Lemmon hypothesis compliance for } \\
\text { ex-post Forward Risk Premium in Power Markets }\end{array}$} \\
\hline \multicolumn{9}{|c|}{ OMIP M Contracts } \\
\hline Quot.Period & $\mathbf{a}$ & $\beta$ & $\mathbf{r}$ & $\mathbf{R}^{2}$ & $\mathbf{t}$ & ta & $t \beta$ & ty \\
\hline All & 3,10 & 0,0557 & $-0,0049$ & $0,46 \%$ & 2,07 & 0,90 & 0,30 & $-0,17$ \\
\hline M-3 & 3,47 & 0,0359 & $-0,0008$ & $0,24 \%$ & 2,08 & 0,82 & 0,15 & $-0,02$ \\
\hline M-2 & 4,28 & $-0,0028$ & $-0,0006$ & $0,01 \%$ & 2,07 & 1,26 & $-0,02$ & $-0,02$ \\
\hline M-1 & 2,55 & 0,0606 & $-0,0069$ & $1 \%$ & 2,07 & 1,09 & 0,48 & $-0,35$ \\
\hline \multicolumn{9}{|c|}{ OMIP Q Contracts } \\
\hline Quot.Period & $\mathbf{a}$ & $\boldsymbol{\beta}$ & $\mathbf{Y}$ & $\mathbf{R}^{2}$ & $\mathbf{t}$ & ta & $\mathbf{t} \boldsymbol{\beta}$ & ty \\
\hline All & $-0,43$ & 0,1144 & $-0,0026$ & $6,20 \%$ & 2,57 & $-0,04$ & 0,24 & $-0,04$ \\
\hline$M-3$ & 3,39 & $-0,0001$ & 0,0035 & $0,63 \%$ & 2,57 & 0,34 & 0,00 & 0,06 \\
\hline M-2 & 2,54 & 0,1278 & $-0,0181$ & $2,42 \%$ & 2,57 & 0,28 & 0,33 & $-0,35$ \\
\hline M-1 & 1,03 & 0,2067 & $-0,0340$ & $12,27 \%$ & 2,57 & 0,13 & 0,62 & $-0,78$ \\
\hline \multicolumn{9}{|c|}{ Powernext M Contracts } \\
\hline Quot.Period & $\mathbf{a}$ & $\beta$ & $\mathbf{Y}$ & $\mathbf{R}^{\mathbf{2}}$ & $\mathbf{t}$ & ta & $t \boldsymbol{\beta}$ & ty \\
\hline All & 18,38 & $-0,0653$ & 0,0003 & $60,11 \%$ & 2,07 & 5,47 & $-4,02$ & 2,82 \\
\hline M-3 & 22,51 & $-0,0901$ & 0,0004 & $65,44 \%$ & 2,07 & 6,09 & $-5,05$ & 3,83 \\
\hline M-2 & 19,59 & $-0,0679$ & 0,0003 & $59,31 \%$ & 2,07 & 5,32 & $-3,81$ & 2,61 \\
\hline M-1 & 12,70 & $-0,0363$ & 0,0001 & $43,33 \%$ & 2,07 & 3,84 & $-2,27$ & 1,32 \\
\hline \multicolumn{9}{|c|}{ Powernext $\mathbf{Q}$ Contracts } \\
\hline Quot.Period & $\mathbf{a}$ & $\boldsymbol{\beta}$ & $\mathbf{Y}$ & $\mathbf{R}^{\mathbf{2}}$ & $\mathbf{t}$ & ta & $\mathbf{t} \boldsymbol{\beta}$ & ty \\
\hline All & 26,52 & $-0,1194$ & 0,0007 & $75,51 \%$ & 2,57 & 3,56 & $-3,29$ & 2,61 \\
\hline M-3 & 25,10 & $-0,0960$ & 0,0005 & $70,59 \%$ & 2,57 & 3,08 & $-2,42$ & 1,67 \\
\hline M-2 & 25,27 & $-0,0854$ & 0,0004 & $68,82 \%$ & 2,57 & 2,96 & $-2,05$ & 1,28 \\
\hline M-1 & 17,77 & $-0,0492$ & 0,0001 & $65,41 \%$ & 2,57 & 2,33 & $-1,33$ & 0,54 \\
\hline \multicolumn{9}{|c|}{ Nord Pool M Contracts } \\
\hline Quot.Period & $\mathbf{a}$ & $\boldsymbol{\beta}$ & $\mathbf{Y}$ & $\mathbf{R}^{2}$ & $\mathbf{t}$ & ta & $t \boldsymbol{\beta}$ & ty \\
\hline All & 11,53 & $-0,2426$ & 0,0056 & $13,38 \%$ & 2,07 & 2,95 & $-1,86$ & 0,16 \\
\hline M-3 & 11,67 & $-0,2545$ & 0,0124 & $10,42 \%$ & 2,07 & 2,49 & $-1,63$ & 0,30 \\
\hline M-2 & 9,47 & $-0,2099$ & 0,0015 & $12,91 \%$ & 2,07 & 2,71 & $-1,81$ & 0,05 \\
\hline M-1 & 4,96 & $-0,0896$ & $-0,0095$ & $8,76 \%$ & 2,07 & 2,28 & $-1,24$ & $-0,50$ \\
\hline \multicolumn{9}{|c|}{ Nord Pool Q Contracts } \\
\hline Quot.Period & $\mathbf{a}$ & $\boldsymbol{\beta}$ & $\mathbf{Y}$ & $\mathbf{R}^{2}$ & $\mathbf{t}$ & ta & $t \boldsymbol{\beta}$ & ty \\
\hline All & 18,01 & $-0,2608$ & $-0,0150$ & $66,30 \%$ & 2,57 & 3,49 & $-3,03$ & $-0,76$ \\
\hline$M-3$ & 19,75 & $-0,2117$ & $-0,0089$ & $22,84 \%$ & 2,57 & 1,79 & $-1,15$ & $-0,21$ \\
\hline M-2 & 13,08 & $-0,0580$ & 0,0139 & $9,18 \%$ & 2,57 & 1,32 & $-0,35$ & 0,37 \\
\hline M-1 & 7,32 & 0,0421 & 0,0328 & $21,58 \%$ & 2,57 & 0,97 & 0,34 & 1,14 \\
\hline
\end{tabular}

Table 4. "Regression results regarding compliance with Bessembinder's \& Lemmon's Hypothesis". Sources: OMIP, OMIE, Powernext and Nord Pool.

The following conclusions can be drawn from the results summarised in Table 4:

- In general, there is relatively poor compliance for the three power markets. No significant differences are obtained between the four Futures series considered for each market. In the case of OMIP, similar results are also obtained by using $F_{\text {eq }}$ instead of $F_{\text {all }}$. Although the quarterly contracts are composed of a limited data set per serie ( 8 values versus 26 of the monthly contracts), $\mathrm{R}^{2}$ statistic is larger for the quarterly contracts.

- OMIP is the least compliant market, as for both monthly and quarterly contracts, coefficient signs for $\beta$ and $y$ are not right as expected from the testable hypothesis, $\mathrm{R}^{2}$ statistic results too low, and t-Student tests (significant values for the coefficients) are not satisfactory. 
- Powernext is the best compliant market in general, as coefficient signs are right, $\mathrm{R}^{2}$ statistic renders reasonable level, and t-Student tests are mostly satisfactory.

- Nord Pool has a medium compliance only for monthly contracts, as for those contracts the coefficient signs tend to be right and t-Student tests are partly satisfactory. On the other hand, reasonable values for $\mathrm{R}^{2}$ statistic are only found for the quarterly contracts.

\section{Reflections about the efficiency of the Iberian Power Futures Market}

This Section intends to provide a qualitative analysis of the price efficiency in the Iberian Power Futures Market compared with other electricity markets, complementing the quantitative findings of the empirical reasearch described in previous Sections.

Samuelson's maturity effect is noticeable in almost all the energy markets considered. This can be caused by the fact that in all these markets there is already an equilibrated mix regarding the trading behaviour of market players (i.e. an adequate proportion of hedgers, speculators, and hybrid players whose behaviour rests between the former ones). In the case of OMIP, such a mix proportion is fulfilled and it seems that there is still much room for new entrants already participating in coexisting forward contracting mechanisms (OTC market, VPP auctions, and CESUR auctions aforementioned). Those potential OMIP trading members belong to the trading categories described above (hedgers: mainly large industrial customers; hybrid: independent energy traders already active in other more mature European power exchanges; speculators: financial entities). The irruption of new members in OMIP would surely bring higher levels of liquidity and presumably better price efficiency.

According to literature review, differences in market organisation and structure cause a heterogeneous development of efficiency levels between neighbouring electricity markets. Regulatory efforts done by the European Regulators Group for Electricity and Gas (ERGEG) within the European Union in order to streamline the integration of regional energy markets will also contribute towards higher levels of efficiency in the Iberian Power Futures Market. In this sense, along year 2009 the Power Exchanges Powernext (France) and EEX (Germany) will merge their spot and 
futures markets. Synergies from both markets will cause efficiency improvements in their market areas and will positively affect the efficiency of the Iberian Power Futures Market. In order to leverage such potential efficiency gains, further regulatory efforts towards the development of auction mechanisms for the FrenchSpanish interconnection are desired. On the other hand, the Iberian power and gas markets are strongly interdependent due to the large participation of electricity and gas trading companies in both markets and the big development of gas infrastructures, combined cycle gas turbines and cogeneration plants in the last years. Therefore, every improvement regarding regulatory harmonization between Spain and Portugal within the MIBEL and the Iberian Gas Market (the so-called MIBGAS) frameworks will also improve the efficiency of the Iberian Power Futures Market.

As previously mentioned, the compulsory call auctions managed by OMIP are a transitory mechanism to foster liquidity in this young market. The competitive nature of those auctions only on selling side makes that their price efficiency is somehow limited. Nonetheless, once satisfactory liquidity levels are reached within the Iberian Power Futures Market, it is assumed that the degree of efficiency of the continuous market will be quite positive. At that stage, it deserves to measure such efficiency considering the weighted average futures prices for the trading sessions where volumes are negotiated. Actually, such weighted average prices are the most natural price indicator to measure the price efficiency of the market. Due to the nascent nature of this market with small initial liquidity, it was preferred to employ other reference prices $\left(F_{\text {eq }}\right.$ and $\left.F_{\text {all }}\right)$. Some inherent price abnormalities from these two indicators have undermined the desired levels of efficiency: in the case of $F_{\text {eq, }}$ the fixed price from distribution companies on the demand side as previously mentioned, and in the case of $F_{\text {all, }}$ the fact that in many sessions at the beginning of OMIP the settlement price was not determined by real trading prices (but by any of the other possibilities of the Methodology described before, e.g., the closing spread). Further research is encouraged regarding measurements of the price efficiency using the best price indicator (i.e. the weighted average price) confirming the gradual improvement of the efficiency of this market caused by the liquidity improvements in the last months.

It is interesting to remark that the design of these compulsory call auctions does not resemble any previous similar experience in other pioneering energy 
derivatives markets. Therefore it is impossible to judge its convenience by directly comparing with analogous cases. On the other hand, it was previously mentioned that other coexistent forward mechanisms exist within MIBEL framework, namely the OTC market, the EPE or VPP auctions, and CESUR or Bilateral Contracting auctions. These two auctions mechanisms within MIBEL context have been designed taking into account previous experiences in other markets (e.g., VPP auctions are consolidated mechanisms in European power markets, like the French, Dutch and Danish ones, and auctions for catering regulated supplies have been previously applied in some US regional markets, as Maryland and New Jersey). Many players active in these coexistent forward mechanisms within MIBEL may use the OMIP platform as a hedge vehicle. Therefore, efficiency gains within MIBEL are expected from a sound regulatory orchestration regarding appropriate supervision of all these market mechanisms. Further research is encouraged to measure in particular if the development of these two other auction mechanisms has brought improved efficiency in the Iberian Power Futures Market managed by OMIP.

\section{Conclusions}

Market efficiency is analysed for the Iberian Power Futures Markets and other European power markets (Powernext and Nord Pool) and fuel markets (Brent, NBP Natural Gas, and EEX ARA Coal) through evaluation of ex-post Forward Risk Premium. The equilibrium price in OMIP compulsory call auctions for distribution companies is not optimal for remuneration purposes as the purchasing costs for regulated supplies tend to be slightly higher than those from OMIP average settlement prices along the whole quotation period, though such a premium is not significant (only around $2 \%$ above). A regulated cap price for each OMIP compulsory call auction could be transitorily applied in order to obtain a lower equilibrium price and therefore diminish regulated costs of supply. Once OMIP continuous market has acceptable liquidity, the settlement price itself would reflect more accurately the market prices and could be used for evaluating the cost of last resort supplies. In the period considered (August 2006 to September 2008), monthly futures contracts have a similar behaviour as quarterly contracts and average risk premia have been positive in power markets (especially until Q4-07) and in gas markets but negative in oil and coal markets. In all the examined markets, the Forward Risk Premium for a futures contract tends to diminish as it approaches maturity. Samuelson's maturity effect - increasing volatility with 
maturity - is noticeable in all the markets except for the British gas market. Compliance with Bessembinder's \& Lemmon's testable hypothesis regarding Forward Risk Premium correlations in Power Markets (negative with variance of spot prices, and positive with skewness of spot prices) is relatively low. Further research is proposed considering an enlarged data set (especially with quarterly contracts) to better test all the hypotheses and draw additional conclusions. Inclusion of calendar contracts may make sense, in order to avoid seasonality effects, although such series are still reduced if OMIP starting point (July 2006) is considered. In general, it can be concluded that none of the markets analysed presents a noticeable level of market efficiency as remarkable forward risk premia exist in all the markets. Regarding Power Markets, the behaviour of OMIP Futures Prices does not differ much in terms of efficiency compared to more mature markets (Powernext and Nord Pool). Although liquidity is still poor in the Iberian Power Futures Market, its price efficiency has improved along with OMIP market development and will increase with further integration of European Power Regional Markets.

\section{Acknowledgements}

We are very grateful to Pablo Villaplana, Vice Director of the Energy Derivatives Division at the Spanish Energy Commission, who has provided us with very valuable insights.

\section{References}

Allen, D.E., \& Cruickshank, S.N. (2002). Empirical Testing of the Samuelson Hypothesis: An Application to Futures Markets in Australia, Singapore and the UK. Working Paper, School of Finance and Business Economics, Edith Cowan University, Joondalup Campus, Western Australia.

Arciniegas, I., \& Barrett, C., \& Marathe, A. (2003). Assessing the efficiency of US electricity markets. Utilities Policy, 11, 75-86.

Armstrong, M., \& Galli, A. (2005). Are day-ahead prices for electricity converging in Continental Europe? An exploratory data approach. CERNA Working Paper.

Avsar, S., \& Goss, B. (2001). Forecast Errors and Efficiency in the US Electricity Futures Market. Australian Economic Papers, 40, pp. 479-499. 
Bessembinder, H., \& Lemmon, M.L. (2002). Equilibrium Pricing and Optimal Hedging in Electricity Forward Markets. The Journal of Finance, LVII(3), 13471382.

Byström, H. (2003). The Hedging Performance of Electricity Futures on the Nordic Power Exchange Nord Pool. Applied Economics, 35, 1-11.

Engel, C. (1996). The forward discount anomaly and the risk premium: A survey of recent evidence. Journal of Empirical Finance, 3(2), 123-192.

Fernández Domínguez, E., \& Xiberta Bernat, J. (2007). Restructuring and generation of electrical energy in the Iberian Peninsula. Energy Policy, 35, 51175129.

Furió, D., \& Meneu, V. (2007). Analysis of the Forward Risk Premium in the Spanish Electricity Market. Valencia University Working Paper.

Lucia, J.J., \& Schwartz, E. (2000). Electricity prices and power derivatives: Evidence from the Nordic Power Exchange. Working Paper 16_00, Anderson Graduate School of Management, Finance, University of California, Los Angeles, USA.

Ministerio de Industria Turismo y Comercio (MITyC) (2006a). ORDEN ITC/2129/2006, de 30 de junio, por la que se regula la contratación a plazo de energía eléctrica por los distribuidores en el segundo semestre de 2006. BOE, 158, 4 de julio de 2006, 25020-25024.

MITyC (2006b). ORDEN ITC/3990/2006, de 28 de diciembre, por la que se regula la contratación a plazo de energía eléctrica por los distribuidores en el primer semestre de 2007. BOE, 312, 30 de diciembre de 2006, 46680-46683.

MITyC (2007). ORDEN ITC/1865/2007, de 22 de junio, por la que se regula la contratación a plazo de energía eléctrica por los distribuidores en el segundo semestre de 2007 y en el primer semestre de 2008. BOE, 152, 26 de junio de 2007, 27314-27318.

MITyC (2008). ORDEN ITC/1934/2008, de 3 de julio, por la que se regula la contratación a plazo de energía eléctrica por los distribuidores en el segundo semestre de 2008. BOE, 162, 5 de julio de 2008, 29517-29520. 
Ministério da Economia e da Inovação (Portugal) (2006). Portaria no 643/2006, de 26 de Junho. Diário da República - I Série-B, no 121 - 26 de Junho de 2006, 4522-4523.

Ministério da Economia e da Inovação (Portugal) (2007a). Despacho no 780/2007. Diário da República - II Série, no 11 - 16 de Janeiro de 2007, 1251-1252.

Ministério da Economia e da Inovação (Portugal) (2007b). Despacho no /2007. Diário da República, 29 de Junho de 2007.

Ministério da Economia e da Inovação (Portugal) (2008). Despacho nº 19098/2008. Diário da República, No 137, Série II, 17 de Julho de 2008.

OMIP (2006): Notice 04/2006 Maximum Price Variation Limits, version of 30 June 2006.

OMIP OMIClear (2008): MIBEL Derivatives Market Operational Guide, version of June 2008.

Samuelson, P. (1965). Proof That Properly Anticipated Prices Fluctuate Randomly. Industrial Management Review, 6(2), 41-49.

Serletis, A. (1992). Maturity Effects in Energy Futures. Energy Economics, 14, 150157.

Shawky, H.A., \& Marathe, A., \& Barrett, C. (2003). A First Look at the Empirical Relation between Spot and Futures Electricity Prices in the United States. The Journal of Futures Markets, 23(10), 931-955.

Sveriges Statens Energimyndigheten (STEM) (2006). (Swedish Energy Agency). Finansiella elmarknaden. Bilaga 5: Översikt av den vetenskapliga litteraturen.

Walls, W. (1999). Volatility, Volume and Maturity in Electricity Futures. Applied Financial Economics, 9, 283-287.

Zachmann, G. (2005). Convergence of Electricity Wholesale Prices in Europe? A Kalman Filter Approach. DIW Discussion Paper 512. 


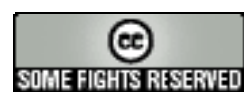

Article's contents are provided on a Attribution-Non Commercial 3.0 Creative commons license. Readers are allowed to copy, distribute and communicate article's contents, provided the author's and Journal of Industrial Engineering and Management's names are included. It must not be used for commercial purposes. To see the complete license contents, please visit http://creativecommons.org/licenses/by-nc/3.0/. 